\title{
Research Paper Resource use efficiency of sapota in Thane district of Maharashtra
}

\section{R.V. SURWASE, P.J. KSHIRSAGAR, J.M. TALATHI, D.B. MALAVE AND G.T. GORE}

See end of the paper for authors' affiliations

Correspondence to :

P.J. KSHIRSAGAR

Department of

Agricultural Economics,

College of Agriculture, Dr.

B.S. Konkan Krishi

Vidyapeeth, Dapoli,

RATNAGIRI (M.S.) INDIA

Email:

sunilkawares@gmail. com

Paper History :

Received : 16.09.2014;

Revised : 03.01.2015;

Accepted : 19.01.2015
ABSTRACT : The study aimed to analyze the resource use efficiency of sapota in Thane district which has high concentration of area under sapota. The multistage random sampling procedure was adopted to choose 120 sample farmers from Dahanu and Palghar tahsils of Thane district which are concentrated near and away from the sea shore, therefore the Villages in Dahanu and Palghar tahsils is divided in to two categories i.e. near the sea shore (Group I) and away from sea shore (Group II).The results of the Cobb-Douglas production revealed that the regression co-efficient for area was found to be significant in case of all the sapota farmers and the co-efficient of multiple determination was $\left(\mathrm{R}_{2}\right) 57$ per cent, 49 per cent, and 44 per cent in case of group I, group II and at overall level, respectively. At near sea shore farms (Group I) the ratio of MVP/MFC is greater than unity in case of male labour, female labour, fertilizer and plant protection indicated that these resources were underutilized which underlines the scope of expanding the use of these inputs. However, in case of away from sea shore (Group II) farms the ratio of MVP/MFC is greater than unity in case of male labour, manures and fertilizer.

KEY WORDS : Resource use efficiency, MVP, MFC and allocative efficiency

HOW TO CITE THIS PAPER : Surwase, R.V., Kshirsagar, P.J., Talathi, J.M., Malave, D.B. and Gore, G.T. (2015). Resource use efficiency of sapota in Thane district of Maharashtra. Internat. Res. J. Agric. Eco. \& Stat., 6 (1) : 57-61. 